\title{
KAPITALIZM LATYNOAMERYKAŃSKI: STRUKTURA I DYNAMIKA
}

\author{
Tomasz Rudowski \\ Uniwersytet Warszawski \\ Instytut Stosunków Międzynarodowych \\ ORCID ID: https://orcid.org/0000-0001-8723-3058 \\ e-mail: tmrudowski@gmail.com
}

\begin{abstract}
Streszczenie: Zamierzeniem artykułu jest analiza i wyjaśnienie struktury i dynamiki kapitalizmu latynoamerykańskiego oraz ukazanie jego typów. Kapitalizm w Ameryce Łacińskiej jest zdecydowanie odmienny od tego, który występuje w państwach Zachodu, dlatego też można zdaniem autora mówić o jego „osobliwości”. W pracy wskazano ponadto główne czynniki determinujące zróżnicowanie kapitalizmu w Ameryce Łacińskiej. Dla ukazania struktury ekonomicznej przedstawiono zagadnienia związane z siłami wytwórczymi i stosunkami produkcji.
\end{abstract}

Słowa kluczowe: kapitalizm, Ameryka Łacińska, relacje centrum-peryferie, kapitalizm hierarchiczny, odmiany kapitalizmu, różnorodność kapitalizmu

\section{WSTĘP}

Fredric Jameson w swoim artykule z 2003 r. napisał, że: „Ktoś kiedyś powiedział, że łatwiej jest wyobrazić sobie koniec świata niż wyobrazić sobie koniec kapitalizmu" [Jameson 2003]. W opinii autora niniejszego artykułu istnieje swoista ponad struktura systemu międzynarodowego, która determinuje politykę światową i jest nią właśnie kapitalizm. Współczesny system światowy jest przykładem gospodarki światowej/gospodarki-świata. Według części badaczy ukształtował się on w XVI w. i potem konsekwentnie rozszerzał na cały świat [Wallerstein 1979; Wallerstein 2007; Dussel 1994; Dussel 2000], wedle innych zaś kapitalizm w sensie społecznym istniał niemal od zawsze [Pobłocki 2017]. Na wymiar przestrzenny światowego systemu składa się hierarchia centrum i peryferii i to ona właśnie dyktuje role ekonomiczne odgrywane przez poszczególne regiony świata. Jednakże aby lepiej zrozumieć dynamikę interakcji i współzależności w gospodarce światowej należy zwrócić uwagę również na wymiary czasowe. Składają się na nie rytmy cykliczne, stałe trendy, sprzeczności oraz kryzysy. To właśnie 
one wraz z wymiarem przestrzennym determinują rozwój systemu światowego. Wskazuje to wszystko na systemowość i współzależność świata/kapitalizmu, ale nie na jego jednolitość. Autor podziela zdanie Henriego Pirenne'a, belgijskiego historyka-mediewisty, który traktował kapitalizm jako „tendencję do stabilnej akumulacji bogactwa" [Pirenne 1914]. Innymi słowy można go zdefiniować jako system nieustannej ekspansji ekonomicznej i rozumieć go nie tylko jako system ekonomiczny, ale także jako/i porządek społeczny [Pobłocki 2017]. Historycznie kapitalizm zawsze potrzebował „rąk roboczych dostatecznie licznych, tanich i posłusznych" [Assorodobraj 1966]. Warunkiem rozwoju kapitalizmu i akumulacji kapitału jest potrzeba dostępu do taniej energii, pracy, żywności i surowców (tzw. tania czwórka istotna dla rozwoju kapitalizmu [Moore, 2015]). Kapitalizm jest zatem nie tylko systemem produkcji, ale także metodą akumulacji. Zdaniem Jana Sowy „Posługując się kategoriami Marksowskiej i marksistowskiej analizy, da się więc powiedzieć, (...) [że:] kapitalizm jest systemem panowania klasowego (rozumienie społeczne), który - być może - jest w stanie realizować swój cel, czyli akumulację dla akumulacji, przy niewolnej organizacji pracy, jednak na pewno robi to najsprawniej, poddając pracę utowarowieniu (rozumienie ekonomiczne), przy czym dzieje się tak nie ze względu na ekonomiczne znaczenie pracy najemnej, ale z powodu jej użyteczności w konstruowaniu ideologicznych interpelacji" [Sowa 2017].

Tezą tej pracy jest stwierdzenie, że kapitalizm w Ameryce Łacińskiej różni się od reszty świata, a także jest odmienny w poszczególnych państwach regionu. Zamierzeniem artykułu jest analiza i wyjaśnienie struktury i dynamiki kapitalizmu latynoamerykańskiego oraz ukazanie jego typów. Kapitalizm w Ameryce Łacińskiej jest zdecydowanie odmiennym od tego, który występuje w państwach Zachodu, dlatego też można zdaniem autora mówić o jego „osobliwości”.

Celem pracy jest podjęcie nowej, nietradycyjnej interpretacji kapitalizmu latynoamerykańskiego. Dla lepszego zrozumienia analizowanego problemu w niniejszej pracy zastosowano różne „,soczewki teoretyczne”, przez które interpretuje się kapitalizm. W opinii autora zastosowanie eklektyzmu analitycznego przyczyni się do pełniejszego poznania omawianego zjawiska [Sil, Katzenstein 2010]. Otwiera to możliwość wyjścia poza ograniczenia, jakie nakłada prowadzenie badań wyłącznie na podstawie metod i narzędzi dostarczanych przez jeden paradygmat. W tym przypadku korzysta się z paradygmatu neostrukturalistycznego oraz perspektywy różnorodności kapitalizmu. Należy w tym miejscu przywołać szkołę zależności wraz z relacjami centrum-peryferie. Stosunki zależności i peryferyjności ulegają również odtworzeniu wewnątrz państwa, a przez to tworzą się zarówno wewnętrzne centra, jak i wewnętrzne peryferie [Galtung 1971]. Celem badań jest charakterystyka wybranych wymiarów gospodarek latynoamerykańskich, czerpiąc również z narzędzi perspektywy różnorodności kapitalizmu. To podejście rozwinęło się po upadku ZSRR i zastępuje ono niejako globalną konfrontację kapitalizmu z komunizmem rywalizacją odmiennych wariantów kapitalizmu działających w różnych krajach oraz regionach świata. Zdaniem Susan 
Strange istnieje w nauce potrzeba syntezy polityki i ekonomii. Dąży do niej ekonomia polityczna stosunków międzynarodowych, która to jest jedną z najprężniej rozwijających się poddziedzin tej dyscypliny w Ameryce Łacińskiej [Gawrycki 2015; Cf. Strange 1988]. Ta politologiczna analiza procesów gospodarczych na poziomie państwa i środowiska międzynarodowego ma za zadanie połączyć studia z zakresu ekonomii ze studiami nad polityką, tak by umożliwić lepsze zrozumienie istoty sił rządzących światem [Gilpin 1987].

Biorąc pod uwagę powyższe założenia $\mathrm{w}$ artykule podjęto próbę pokazania i wyjaśnienia fenomenu „osobności” kapitalizmu latynoamerykańskiego analizując takie zagadnienia jak: 1) podziały i warianty kapitalizmu w świecie, 2) typy kapitalizmu w Ameryce Łacińskiej oraz 3) analiza struktury ekonomicznej poszczególnych państw.

$$
* * *
$$

W ramach systemu kapitalistycznego badacze wyróżniają różne jego podziały i warianty: kapitalizm wolnorynkowy (państwa anglosaskie), kapitalizm koordynowany/koordynacyjny (Niemcy i państwa kontynentalne UE), kapitalizm nastawiony na rozwój (Japonia, Korea, państwa Azji Południowo-Wschodniej) [Pauly, Reich 1997; Czaputowicz 2008]. Z kolei francuski ekonomista, Bruno Amable, wyróżnił aż pięć modeli kapitalizmu: rynkowy (państwa anglosaskie), socjaldemokratyczny (państwa skandynawskie), azjatycki (Japonia, Korea Południowa), śródziemnomorski (Europa Południowa) oraz europejski kapitalizm kontynentalny (Europa Zachodnia) [Amable 2003]. Można spotkać również podział na: model liberalnej gospodarki rynkowej (liberal market economy, LME) i skoordynowanej gospodarki rynkowej (coordinated market economy, CME) [Hall, Soskice, 2001] czy też: kapitalizm liberalny i kapitalizm kierowany przez państwo [Sheahan 2002].

Kapitalizm występujący w Ameryce Łacińskiej jest jednak odmienny od wspomnianych już typów kapitalizmu. Po pierwsze Ameryka Łacińska, jak i inne regiony peryferyjne wraz ze swoim kapitalizmem zależnym (peryferyjnym) stała się częścią gospodarki światowej sprowadzonej do roli eksportera produktów rolnych i surowców, oraz importera towarów przemysłowych, nowych technologii, kapitału, czy nawet w znacznym okresie siły roboczej [Rudowski 2017a; Dos Santos 1979].

Kapitalizm zależny zdaniem Henryka Szlajfera należy traktować bardziej jako paradygmat, niż substytut historii. Twierdzi on, iż ,jeśli bowiem przez kapitalizm zależny nie rozumiemy statycznego obrazu rzeczywistości skonstruowanej i spetryfikowanej w pierwszych latach podboju, lecz proces kształtowania specyficznych struktur ekonomicznych i zachowań w długim okresie, podporządkowanych wymogom akumulacji, reagujących na bodźce oraz zmiany zewnętrzne i wewnętrzne, obawa przed uproszczeniami, jaka zrodziła koncepcję 
kolonialnego sposobu produkcji przestaje być uzasadniona" [Szlajfer 1985]. Z kolei zaś brazylijski badacz, Ruy Mauro Marini, przez „zależność” pojmował „relacje podporządkowania pomiędzy formalnie niezależnymi narodami, zgodnie z którymi stosunki produkcji podległych narodów są modyfikowane czy odtwarzane w celu zapewnienia reprodukcji rozszerzonej zależności" [Marini 1973]. W konsekwencji jego zdaniem prowadzi to do wzrostu zależności. W państwach latynoamerykańskich, podobnie jak w innych krajach peryferyjnych, modele rozwoju charakteryzują się dwoma podstawowymi cechami: heterodoksją strukturalną (połączenie nowoczesnych i zaawansowanych form produkcji z zacofanymi) [Pinto 1970; Rodríguez 1998] i relacjami dominacji i zależności, które dają prymat krajom centrum w gospodarce światowej.

Włączenie Ameryki Łacińskiej i jej struktur społeczno-gospodarczych w orbitę światowego systemu imperialistycznego nie tylko doprowadziło do przekształcenia tychże struktur, ale również przesądziło o ich kapitalistycznym charakterze [Stemplowski 1979]. Według brazylijskiego socjologa Octavio Ianniego zależność jest pewnym historycznym procesem konstytutywnym i charakteryzuje istotę społeczeństw Ameryki Łacińskiej [Ianni, 1987; Rudowski 2017a].

W zaproponowanym przez autora latynoamerykańskim hybrydowym modelu rozwoju struktura ekonomiczna wpływa na kształt polityki rozwoju państw Ameryki Łacińskiej, która jest elementem składowym całokształtu nieekonomicznych instytucji społecznych. Ponadto model ukazuje korelację pomiędzy strukturą ekonomiczną a zbiorem tychże instytucji, w skład których wchodzą również m.in. instytucje i polityka państw latynoamerykańskich w zakresie rozwoju. Zarówno na strukturę ekonomiczną, jak i strategie rozwoju wpływa stan zależności od państw centrum spowodowany postkolonialnym systemem zależności wraz z niekorzystnymi warunkami wymiany, co w konsekwencji sprowadza Amerykę Łacińską do roli peryferyjnej. Analizowanemu regionowi narzucono funkcję rezerwuaru tanich zasobów naturalnych, taniej siły roboczej, jak i rynków zbytu dla państw centrum. Chociaż owe zjawisko może być w pewnym stopniu odbierane jako forma zależności centrum od peryferii, jednak nie jest to zależność prostego typu, nie ma ona kluczowego znaczenia i odpowiada właściwie jedynie potrzebom i interesom dominujących społeczeństw kapitalistycznych, pozostawiając region latynoamerykański podporządkowany idei zaspokajania potrzeb centrum. Dowodzi tego fakt, że w większym stopniu uzależniona jest Ameryka Łacińska (peryferie) od importerów, nabywców i inwestorów państw dominujących niż państwa centrum od eksportu latynoamerykańskiego. Poza tym „zależność” w zaspokajaniu potrzeb centrum ograniczona jest wyłącznie do sektora gospodarczego i nie przekłada się ona na inne obszary, takie jak np.: polityka, prawo, kultura, nauka czy technologia. To sprawia, że należy traktować ją jako część systemu zależności (peryferii od centrum) ze względu m.in. na to, iż petryfikuje obecny międzynarodowy podział pracy, który przyczynił się do „umknięcia” Ameryce Łacińskiej transformacji innowacyjnej. W rezultacie autor odrzuca tezę mówiącą o „wzajemnej zależności” czy „rosnącej współzależności” 
pomiędzy Ameryką Łacińską a centrum. Powyższe relacje przedstawia poniższy schemat [Rudowski 2017b].

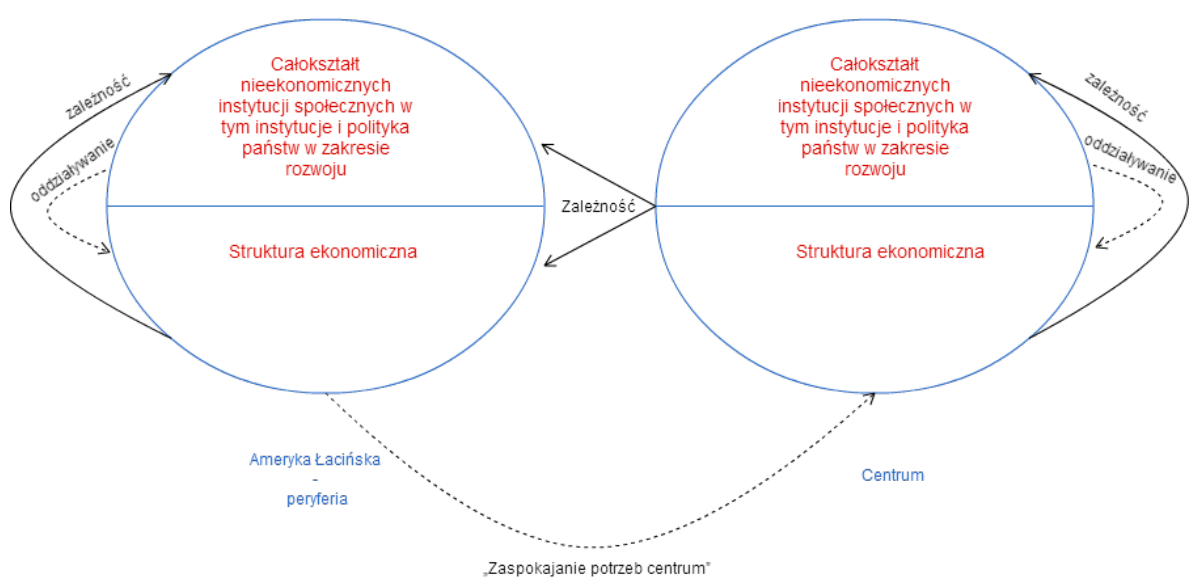

Schemat 1. Relacje zachodzace pomiędzy struktura ekonomiczna a całokształtem nieekonomicznych instytucji społecznych w ramach koncepcji centrum-peryferie

Źródło: Opracowanie własne

Kolejną cechą świadczącą o odrębności kapitalizmu latynoamerykańskiego jest jego hierarchiczność. W Ameryce Łacińskiej rozwinął się „hierarchiczny” kapitalizm, zdominowany przez duże zagraniczne i krajowe przedsiębiorstwa, rozdrobnione rynki pracy, niewielki kapitał własny przedsiębiorstw lokalnych i nierówność społeczną. Na pytanie: Co odróżnia kapitalizm w Ameryce Łacińskiej? północnoamerykański badacz, Ben Ross Schneider, autor pracy „Hierarchical Capitalism in Latin America: Business, Labor, and the Challenges of Equitable Development" odpowiada, że są cztery takie cechy: głęboka penetracja międzynarodowych korporacji (30-50\% największych firm w każdym kraju w posiadaniu zagranicznego kapitału - w przypadku Argentyny więcej); duże i zróżnicowane koncerny rodzinne; segmentowy rynek pracy (wiele zmian personalnych, duży sektor nieformalny i liczne ograniczenia regulacyjne; niski poziom wykształcenia [Rebossio 2015].

Hierarchiczny kapitalizm występuje nie tylko w Ameryce Łacińskiej, ale także w innych krajach, takich jak Turcja czy Tajlandia. Hierarchia jest widoczna w wielu miejscach, na przykład wewnątrz grup kapitałowych. Zwykle to jedna rodzina jest właścicielem danej grupy, nie mają one wielu udziałowców, tak jak w Europie. Często te grupy nie uczestniczą w tworzeniu nowych firm, nie ma tam relacji rynkowych, zaś w samych grupach istnieją silne hierarchie, ponieważ związki zawodowe są słabsze, a pracownicy mają mniej praw niż np. w UE.

Praca Bena Rossa Schneidera dowodzi, że Ameryka Łacińska ma specyficzny, trwały rodzaj hierarchicznego kapitalizmu, który charakteryzuje się wielonarodowymi korporacjami, zdywersyfikowanymi grupami biznesowymi, niskimi 
umiejętnościami i segmentacją rynku pracy. Z biegiem czasu komplementarność instytucjonalna łączy w sobie cechy ładu korporacyjnego i rynków pracy, a przez to przyczynia się do odporności instytucjonalnej. Systemy polityczne na ogół sprzyjały elitom i osobom uprzywilejowanym, które dodatkowo wzmacniały istniejące instytucje i komplementarność. Hierarchiczny kapitalizm nie promuje wzrostu produktywności, dobrych miejsc pracy ani sprawiedliwego rozwoju, a skuteczność strategii rozwoju zależy od rozwiązania problemu negatywnej komplementarności instytucjonalnej [Ross Schneider 2013].

Doświadczenia płynące z Ameryki Łacińskiej pozwalają na odrzucenie funkcjonalistycznych stanowisk popularnych od czasów Friedricha Hayeka mówiących o tym, że instytucje powstają i działają z powodów efektywnościowych [Hayek 1967]. Trudnym zagadnieniem jest odpowiedź na pytanie z czyjego punktu widzenia instytucje powinny być efektywne? W opinii Bruno Amable'a powstanie konkretnych instytucji jest wyrazem „,kompromisu politycznego”, między różnymi grupami interesów forsującymi swoje, często sprzeczne cele, a tym samym każda zmiana instytucjonalna narusza istniejący układ interesów. Zdaniem Amable'a różne modele kapitalizmu odzwierciadlają ,,specyficzne kompromisy społeczne w sprawie instytucji, [a kwestia] zmiany instytucjonalnej jest przedmiotem zainteresowania ekonomii politycznej [Amable 2003; Rapacki... 2018]. Ponadto Amable stwierdził, że „,modeli kapitalizmu nie powinno się rozpatrywać wyłącznie jako zbioru mniej lub bardziej przypadkowych form instytucjonalnych, ale w szerszym ujęciu, uwzględniając m.in. występujące pomiędzy nimi powiązania - w tym relacje oparte na komplementarności, co pozwala połączyć specyficzne instytucjonalne formy każdego modelu w spójną całość" [Amable 2003].

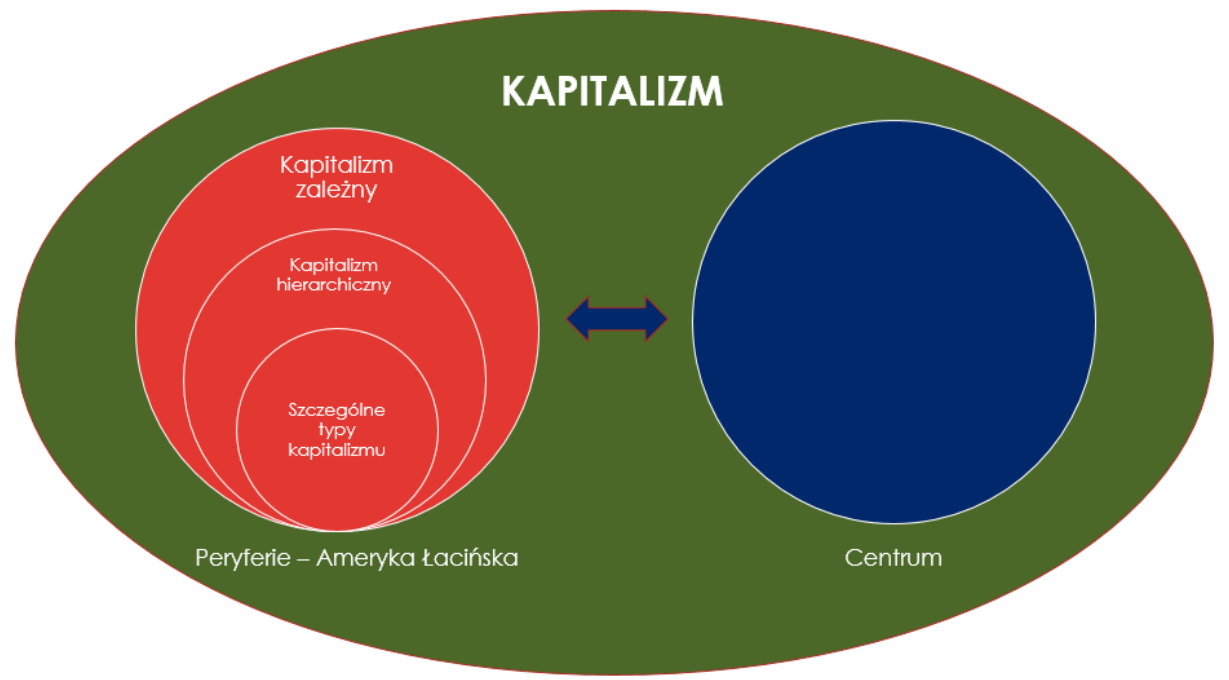

Schemat 2. Różnorodność kapitalizmu z uwzględnieniem Ameryki Łacińskiej

Źródło: Opracowanie własne 
Współcześnie można wyróżnić różne typy kapitalizmu w Ameryce Łacińskiej. Typ pierwszy reprezentowany przez Brazylię charakteryzuje się kapitalizmem zorientowanym na państwo i rynek wewnętrzny, choć przy tym również wspierającym swoich eksporterów. Drugim typem jest kapitalizm zorientowany na rynki zewnętrzne, a za jego przykład może uchodzić Chile, gdzie kapitalizm jest regulowany przez państwo, ale istnieje zależność od kapitału prywatnego. Trzeci typ kapitalizmu reprezentuje Meksyk, który charakteryzuje się zderegulowanym kapitalizmem podporządkowanym rynkowi zewnętrznemu - kapitalizm międzynarodowego podwykonawstwa. Jego obrazem jest meksykańska gospodarka zajmująca się głównie podwykonawstwem podzespołów dla zewnętrznych przedsiębiorstw. Kolejny typ kapitalizmu (mieszany / patchworkowy) reprezentuje Argentyna - niestabilna hybryda, która w różnych okresach, zależnie od rządzących i dominujących aktualnie poglądów, jest dostosowywana do wymienionych wcześniej trzech rodzajów kapitalizmu. Piątą odmianą kapitalizmu latynoamerykańskiego jest typ rentierski, w którym relacje społeczno-polityczne są niemal wyłącznie redystrybucyjne: określa je istnienie zasobów państwowych, które są dystrybuowane bez żadnego produktywnego celu. Ten model istnieje w Wenezueli, a częściowo w Ekwadorze, Boliwii i Meksyku [Bizberg, Théret 2015]. Różnice między Argentyną, Brazylią, Meksykiem, Chile, i Wenezuelą które będą brane pod uwagę, obejmują następujące aspekty: dominująca koalicja społeczno-polityczna, organizacje społeczne i ich zdolność do regulowania rynku pracy, reżim walutowy i finansowy oraz forma państwa [Bizberg, Théret 2015]. Należy stwierdzić, że państwa Ameryki Łacińskiej miały podobną trajektorię rozwoju kapitalizmu aż do początków lat siedemdziesiątych XX w.

W pierwszym typie kapitalizmu (Brazylia) mamy do czynienia z wyraźną i znaczącą rolą państwa i silnymi związkami zawodowymi, oraz dużymi regulacjami. W typie drugim instytucje te nie pełnią tak istotnej funkcji. Trzeci typ kapitalizmu charakteryzuje się niskim interwencjonizmem państwa, koordynacja między związkami zawodowymi a kapitałem praktycznie nie istnieje z powodu słabości podmiotów społecznych, a system stosunków produkcji zdominowany jest przez elastyczność oraz szczątkowy system opieki społecznej [Bizberg 2015]. Piąty typ kapitalizmu w Ameryce Łacińskiej wyróżnia się dystrybucyjną rolą państwa. Utrzymanie ukierunkowania gospodarek na eksploatację zasobów naturalnych i eksport towarów niskoprzetworzonych i nieinnowacyjnych, wzmacnia historyczny wzorzec ekstrakcyjny, który nie sprzyja produktywności ani sprawiedliwszej dystrybucji dochodów, ponieważ koncentruje się na podmiotach tradycyjnie dominujących (grupy lokalne i firmy międzynarodowe), utrwalając model rentierski. Przewaga strukturalnej inercji uniemożliwia absorpcję nowych paradygmatów technologicznych i wzrost innowacyjności w oparciu o wiedzę, gospodarka ulega bezwładności, która się samoczynnie podtrzymuje [Cimoli, Rovira 2008; cf. Hernández López 2017].

W produkcji Chile i Wenezueli dominują surowce, w Argentynie także i one dominują, choć wytwarza się również znaczną liczbę artykułów przemysłowych. 
Podobnie jest w Brazylii, natomiast Meksyk skupia się na produkcji przemysłowej. $Z$ analizowanych państw politykę antycykliczną prowadzi Chile, Brazylia i Argentyna, a procykliczną Meksyk. W Brazylii i Argentynie panuje tolerancja wobec umiarkowanej inflacji, Wenezuela od lat zmaga się z hiperinflacją. Wysoka presja fiskalna ma miejsce w Argentynie i Brazylii, w pozostałych analizowanych państwach zaś jest niska, bądź średnio-niska. $Z$ analizowanych państw tylko Chile i Meksyk są praktycznie wolne od protekcjonizmu handlowego. Co do interwencji państwa to należy określić ją w Brazylii mianem neorozwojowej (m.in. silna polityka przemysłowa), podobnie w Argentynie (choć z ograniczeniami), w Chile-liberalno-pomocniczej, w Meksyku liberalno-minimalistycznej, a w Wenezueli interwencjonistyczno-ekstraktywistycznej. Należy pamiętać, że Bank Centralny jest niezależny tylko w Meksyku i Chile. W kwestii stosunków pomiędzy pracodawcami a pracownikami należy stwierdzić, że tylko w Meksyku mamy do czynienia z niską formalizacją. Konkurencyjność Chile i Meksyku oparta jest na niskich płacach i niskich kosztach społecznych, z kolei Argentyny i Brazylii na wzroście rynku wewnętrznego [Bizberg 2015]. Nie mniej ważną kwestią jest system edukacji. W państwach Ameryki Łacińskiej jest on generalnie niedofinansowany, nauczyciele są źle opłacani, nie zawsze dysponują odpowiednimi kwalifikacjami, a także poziom samego nauczania nie zawsze jest dobry, co przekłada się na niski poziom edukacji. Wskazują na to słabe wyniki w badaniu PISA. W teście z matematyki uczniowie z Argentyny zajęli 58 miejsce, z Brazylii -68 , z Chile - 50, z Meksyku - 59, Wenezuela - nie uczestniczyła w badaniu. Na 73 badane państwa, ostatnie miejsce zajęli uczniowie z Republiki Dominikany [OECD 2016].

\section{WNIOSKI}

Przedstawiona analiza nakreśla przesłanki do dyskusji na temat kapitalizmu latynoamerykańskiego. Artykuł ten ma na celu wznowienie debaty na temat natury kapitalizmu w Ameryce Łacińskiej i powiązanie tej dyskusji z pokrewnymi badaniami nad różnorodnością kapitalizmu w innych częściach świata.

Autor zgadza się ze stwierdzeniem Ilána Bizberga i Bruna Théreta, że w czasach globalizacji jesteśmy świadkami coraz mniejszej zbieżności i bardziej wyrazistego zróżnicowania gospodarek Ameryki Łacińskiej. Proces ten postępuje do tego stopnia, że Brazylia jawi się jako autonomiczna siła, jeden z największych „zaawansowanych rynków wschodzących”, podczas gdy Meksyk pogrąża się w zależności od gospodarki Stanów Zjednoczonych. Argentyna nie przestała oscylować pomiędzy dużymi skokami do przodu i gwałtownymi niepowodzeniami, w taki sposób, że dotychczasowa zmienność utrudnia prognozowanie. Wydaje się, że Chile udało się z sukcesem włączyć do gospodarki światowej, ale wykazuje poważne deficyty np. w zakresie dystrybucji dochodów (duże nierówności społeczne), które mogą zakłócić rozwój tego kraju [Bizberg, Théret 2015]. Wene- 
zuela natomiast pogrąża się w kryzysie społeczno-gospodarczym i politycznym doprowadzając do emigracji oraz niespotykanego dotychczas w tym państwie kryzysu humanitarnego.

Regionalne czy też krajowe odmiany kapitalizmu zależą od zdolności instytucjonalnej do modulacji swoich sił na rynku światowym, a także od zdefiniowania relacji między podmiotami. To przekłada się na stosunki produkcji, a także na możliwość inkluzji oraz innowacji [Hernández López 2017; Rudowski 2017b]. Na podstawie przeprowadzonej analizy do czynników determinujących zróżnicowanie kapitalizmu w Ameryce Łacińskiej w opinii autora można zaliczyć: formy integracji z gospodarką światową; ekonomiczną rolę państwa i strukturę produkcji; system finansowy; naturę relacji między państwem a sektorem przedsiębiorstw; system zabezpieczenia społecznego; system edukacji i tworzenia wiedzy.

Propozycja ta ma charakter hipotetyczny i nie jest wykluczone, że dalszy tok badań może ją sfalsyfikować. Jest ona wyzwaniem dla dalszych studiów nad Ameryką Łacińską i odmianami kapitalizmu. Autor ma nadzieje, że będzie ona przydatnym instrumentem do wychwycenia i zrozumienia specyfiki Ameryki Łacińskiej w kontekście różnorodności kapitalizmu.

Title: Latin American Capitalism: Structure and Dynamics

\begin{abstract}
The aim of the article is to analyze and explain the structure and dynamics of Latin American capitalism as well as to discuss its types. Capitalism in Latin America is undoubtedly different from capitalism that exists in Western countries and thus, in the author's view, it is possible to talk about its "peculiarities". The study also analyzes the main factors determining the varieties of capitalism in Latin America. In order to present the economic structure, it is necessary to discuss the issues concerning the forces of production and the relations of production.
\end{abstract}

Keywords: capitalism, Latin America, center-periphery relations, hierarchical capitalism, varieties of capitalism, diversity of capitalism

\title{
BIBLIOGRAFIA
}

1. Amable B., 2003, The diversity of modern capitalism, Oxford University Press, Oxford, s. 6, 9-10.

2. Assorodobraj N., 1966, Początki klasy robotniczej: problem rąk roboczych w przemyśle polskim epoki stanistawowskiej, PWN, Warszawa, s. 153.

3. Bizberg I., 2015, Tipos de capitalismo en América Latina, [w:] Variedades del capitalismo en América Latina: los casos de México, Brasil, Argentina y Chile, red. I. Bizberg, El Colegio de México, México.

4. Bizberg I., Théret B., 2015, Introducción, [w:] Variedades del capitalismo en América Latina: los casos de México, Brasil, Argentina y Chile, red. I. Bizberg, El Colegio de México, México.

5. Cimoli M., Rovira S., 2008, Elites and Structural Inertia in Latin America: An Introductory Note on the Political Economy of Development, "Journal of Economic Issues", vol. XLII, no. 2, s. 345 .

6. Czaputowicz J., 2008, Teorie stosunków międzynarodowych, PWN, Warszawa, s. 158-159, 162. 
7. Dos Santos T., 1979, La estructura de la dependencia, [w:] Economía Internacional, t. II: Teorías del imperialismo, la independencia y su evidencia histórica, Fondo de Cultura Económica, México, s. 216-217.

8. Dussel E., 1994, 1492. El encubrimiento del otro. Hacia el origen del mito de la modernidad, Plural Editores, La Paz.

9. Dussel E., 2000, Europa, modernidad y eurocentrismo, [w:] La colonidad del saber, eurocentrismo y ciencias sociales. Perspectivas latinoamericanas, red. E. Lander, CLACSO-UNESCO, Buenos Aires.

10. Galtung J., 1971, A Structural Theory of Imperialism, "Journal of Peace Research", vol. 8, no. 2, s. 83-86.

11. Gawrycki M. F., 2015, Latynoamerykańska ekonomia polityczna stosunków międzynarodowych: studium endemicznej myśli, „Stosunki Międzynarodowe”, t.51, nr 2, s. 71.

12. Gilpin R., 1987, The Political Economy of International Relations, Princeton University Press, Princeton, s. 3.

13. Hall P. A., Soskice D., (red.), 2001, Varieties of capitalism: The institutional foundations of comparative advantage, OUP Oxford, Oxford.

14. Hayek F. A., 1967, Notes on the Evolution of System of Rules of Conduct, [w:] Studies in Philosophy, Politics and Economics, F. A. Hayek, Chicago University Press, Chicago, s. 66-81.

15. Hernández López M. H., 2017, Variedades de capitalismo, implicaciones para el desarrollo de América Latina. Economía teoría y práctica, s. 218, 224.

16. Ianni O., 1987, Kryzys państwa oligarchicznego w Ameryce Łacińskiej, [w:] Ameryka Łacińska. Dyskusja o rozwoju, red. Stemplowski Ryszard, Czytelnik, Warszawa, s. 157-182.

17. Jameson F., 2003, Future City, "New Left Review", no. 21 (May-June), s. 76.

18. Marini R. M., 1973, Dialéctica de la dependencia, Ediciones Era, México, s. 18.

19. Moore J. W., 2015, Capitalism in the Web of Life: Ecology and the Accumulation of Capital, Verso, London.

20. OECD, 2016, Launch of PISA 2015 Results, OECD PISA, London, https://www.oecd.org/pisa/ launch-of-pisa-2015-results.htm (dostęp: 15.01.2019).

21. Pauly L. W., Reich, S., 1997, National Structures and Multinational Corporate Behavior, Enduring Differences in the Age of Globalization, „International Organization”, vol. 51, no. 1 (Winter), s. 7.

22. Pinto A., 1970, Naturaleza e implicaciones de la „heterogeneidad estructural” de la América Latina, „El Trimestre Económico”, t. XXXVII, nr 145, s. 85.

23. Pirenne H., 1914, The Stages in the Social History of Capitalism, "The American Historical Review", vol. 19/3.

24. Pobłocki K., 2017, Kapitalizm. Historia krótkiego trwania, Fundacja Bęc Zmiana, Warszawa.

25. Rapacki R., Gardawski J., Czerniak A., Horbaczewska B., Karbowski A., Maszczyk M., Próchniak P., 2018, Wyłaniające się odmiany kapitalizmu w Europie Środkowo-Wschodniej: przegląd badań, „Ekonomista”, nr 5, s. 532.

26. Rebossio A., 2015, El capitalismo latinoamericano es jerárquico, no lleva al desarrollo, https:// blogs.elpais.com/eco-americano/2015/03/el-capitalismo-latinoamericano-es-jer\%C3\%A1rquico-no-lleva-al-desarrollo-.html (dostęp 14.01.2019).

27. Rodríguez O., 1998, Heterogeneidad estructural y empleo, CEPAL, Río de Janeiro, http://www. cepal.org/publicaciones/xml/0/19390/rodrig.htm (dostęp: 26.12.2018).

28. Ross Schneider, B., 2013, Hierarchical Capitalism in Latin America: Business, Labor, and the Challenges of Equitable Development, Cambridge University Press, New York and Cambridge. 
29. Rudowski T., 2017a, Kapitalizm zależny a państwo w Ameryce Łacińskiej w ujęciu teorii dependencji, „Ameryka Łacińska. Kwartalnik Analityczno-Informacyjny”, nr 1 (95), 7-26.

30. Rudowski T., 2017b, Modele rozwoju w Ameryce Lacińskiej. Strategie modernizacji państw, Biblioteka Iberyjska, Warszawa, s. 18, 143-146.

31. Sheahan J., 2002, Alternative Models of Capitalism in Latin America, [w:] Models of Capitalism: Lessons for Latin America, red. E. Huber, The Pennsylvania State University Press, University Park, s. 25-34.

32. Sil R., Katzenstein P. J., 2010, Beyond Paradigms: Analytic Eclecticism in the Study of World Politics, Palgrave Macmillan, Houndmills/Basingstoke.

33. Sowa J., 2017, Kapitalizm. Historia krótkiego trwania - Dziewiętnaście Long Reads o „,Tysiącu lat niewolnictwa”, „Praktyka Teoretyczna”, nr 4(26), s. 370.

34. Stemplowski R., 1979, Spoleczeństwa i państwa latynoamerykańskie u progu epoki współczesnej, [w:] Dzieje Ameryki Łacińskiej, red. Łepkowski Tadeusz, t. 2, Książka i Wiedza, Warszawa, s. 210.

35. Strange S., 1988, States and Markets, Pinter, London.

36. Szlajfer H., 1985, Modernizacja zależności. Kapitalizm i rozwój w Ameryce Łacińskiej, Ossolineum, Wrocław, s. 66.

37. Wallerstein I., 1979, The Capitalist World-Economy, Cambridge University Press, CambridgeNew York.

38. Wallerstein I., 2007, Analiza systemów-światów. Wprowadzenie, Dialog, Warszawa. 